\title{
THE IMPLEMENTATION OF THE OPTIMIZED DRIP IRRIGATION SYSTEM IN AGRICULTURE
}

\section{J.B. SAPAEV ${ }^{1}$, A.ARIFJANOV ${ }^{1}$, I.B. SAPAEV ${ }^{1}$, G.E. ESHCHANOVA ${ }^{1}$, B. SAPAEV ${ }^{2}$, U.A.NULLAEV ${ }^{1}$, A.M.AKHMEDOV ${ }^{1}$, D.E. NORBEKOV ${ }^{3}$}

${ }^{I}$ Tashkent Institute of Irrigation and Agricultural Mechanization Engineers

${ }^{2}$ Tashkent State Agrarian University

${ }^{3}$ Tashkent Financial Institute

\begin{abstract}
In the article the optimized drip irrigation system is introduced. This research process focuses on drip irrigation of plants per hectare, in which has the control of water base, amount of water in the pipe, the speed of water in the pipe, soil moisture, salinity, temperature, soil water ph, automatic pressure regulator valvesare proven to work automatically. The system provides economic indicators for one hectare of land area and analysis of complete replacement of imported products.
\end{abstract}

KEYWORDS: Water Base, Quantity, Speed, Soil Moisture, Salinity, Ph Indicator, Pressure Regulator Valves

Received: Jun 08, 2020; Accepted: Jun 28, 2020; Published: Sep 18, 2020; Paper Id.: IJMPERDJUN20201332

\section{INTRODUCTION}

Today, with the rapid development of technical and economic indicators of agriculture, the need for water is growing. In this regard, in order to save water, the system of drip irrigation of agricultural lands has been widely introduced. Examples include countries using drip irrigation and their performance. At present time drip irrigation is used in many countries on earth, where water resources are limited and absent. In the world, more than 1.2 million hectares of land are irrigated by drip irrigation (USA - 888 thousand hectares, Spain - 34 thousand hectares, Israel - more than 100 thousand hectares. Australia - about 50 thousand hectares, Italy - 32 thousand hectares, France - 20 thousand hectares, China - 20 thousand hectares, South Korea - 15 thousand hectares). For example, in the State of Israel, the crop irrigation is carried out in $100 \%$ pressure system, that is, drip irrigation, which works under pressure generated by pumping stations, sprinklers and other water resources that can be used sparingly [1].

Several scientific studies have been carried out on drip irrigation system, for example: Russian scientists Yasonidi O.E. [2], Markov Yu.A. [3], scientist of the Crimean Federal University V.N.Storchows. [4,5], from Volgograd scientists. Professor A.D. Akhmedov, A.A. Temerev, E.Yu. Galiullina, from Republican scientists M.Kh. Khamidov, Kh.I. Shukurlaev, A. B.Maksamataliev [6], A.G. Bezborodov, G.A. Bezborodov [7], R. Bakiev [8], Z.A. Artukmetov, M. Shodmanov [9], Z.A. Artukmetov, Kh.Sh. Sheraliev [10], Z.A. Artukmetov, Kh.N.Allanov [11], Sh. Azizov [12], M. Khamidov, X.I. Shukurlaev, I. Begmatov, A. Mamataliev [13], R.T.Gazieva, A. M.Usmonov, E. O.Ozodov [14], S.A. Mamatov [15], Kh.T. Rakhimov [16], A. M.Arifdzhanov, A.M.Fatkhullaev, K. T. Rakhimovsworks provide examples about the convenience and operation of drip irrigation systems, but the automation process has not been fully proven, our studies show that the irrigation process of one 
hectare land in an automated system is optimized without intervention human, soil moisture, temperature, salinity and by the difference of the amount of ph from distance.

A drip irrigation system is the irrigation network designed to deliver the necessarily amount of water equal to the water of plants to its root layer. The difference between drip irrigation and other irrigation methods is that water is distributed evenly over the field according to the needs of crops. The sown areas of the field are uniformly moistened. No excess moisture appears in the soil. When watering, the moisture in the soil exceeds the required amount and the crop is immersed in water, and between watering the soil dries out and the plant remains without water.

As a result, the plant uses its energy to overcome these cases. With drip irrigation, the moisture content of the root layer of the crop is kept constant and the plant uses all its energy to create its own crop. Studies show that with drip irrigation the soil moisture permanently suits the needs of crops [18].

\section{METHODS}

General diagram of a drip irrigation system. A drip irrigation system usually includes the following elements:

- $\quad$ water source (sink, pool);

- pumping device;

- device for preparing fertilizer solution and adding it to water;

- water treatment (filtering) equipment;

- trunkand distribution pipelines;

- devices connecting parts of the system;

- pressure regulators;

- drip hoses;

- control and measuring equipment.

The research results were obtained for one hectare of land; Figure 1 shows the diagram of drip irrigation system.

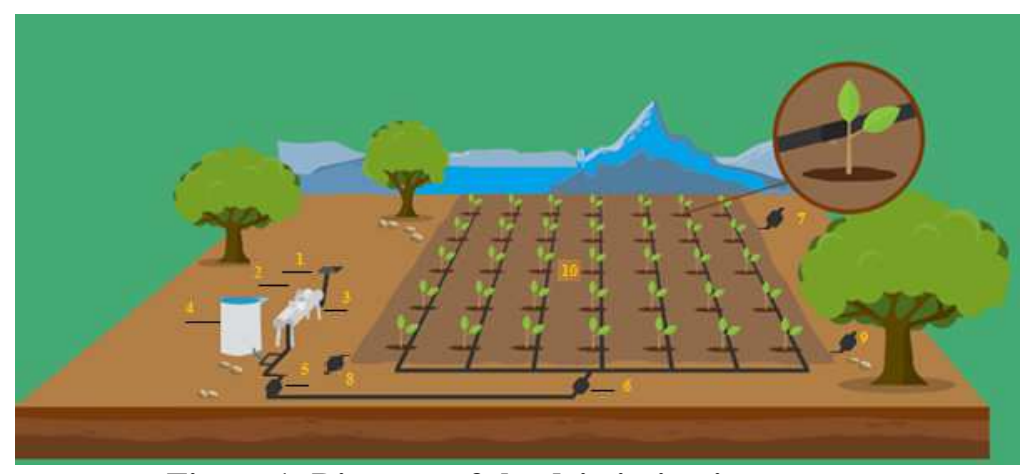

Figure 1: Diagram of the drip irrigation system

General view of the drip irrigation system in Figure 1; 1 - photo relay for opening and closing water; 2 - green LED indicating that water base is full; 3 - red LED indicating a decrease in the water base; 4- device for preparation of fertilizer solution (Venturi injector); 5 - sand filter and device for determining the water pressure in the pipe; 6 - device for 
determining the speed of water in the pipe; 7 - light-emitting diode transmitting plant dehydration to the water base; 8 thermo hygrometer for determining soil moisture and temperature; 9 - device for determining the ph of soil; 10 - pressure regulator valves (dripping).

\section{Drip Irrigation System Components}

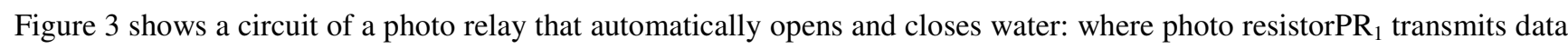
to K1-relay for turning on and off when a crack signal is received, resistor with value of $\mathrm{R}_{1}-10 \mathrm{k}$, NPN-based on VT1silicon and VT2- silicon based on P-N-P KT3107 transistor based on PNP serves as a signal amplifier, K1.1 - a switch.

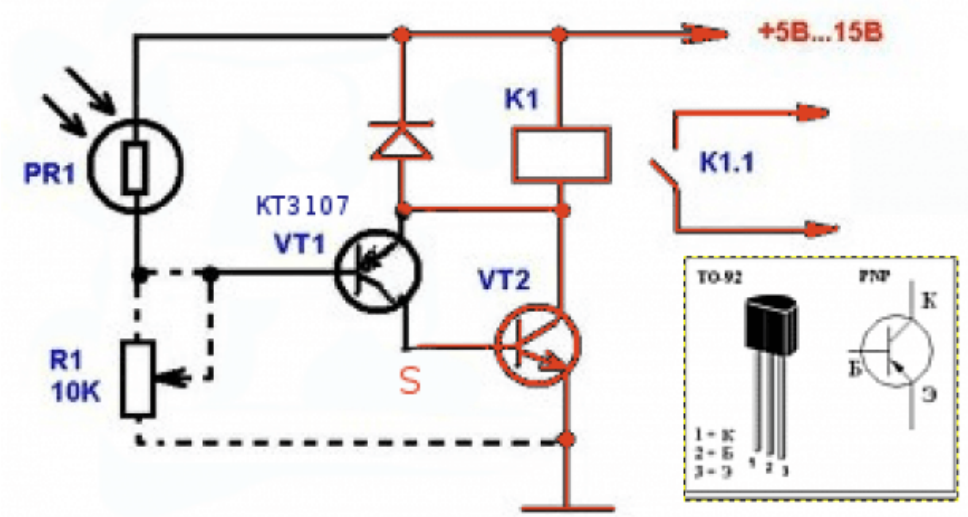

Figure 2: Drawing of the water relay opening and closing relay.

Figure 3 shows the LED diagram in the mode based on liquid permeability, this diagram serves to perform a function showing the decrease and filling of water in the base.

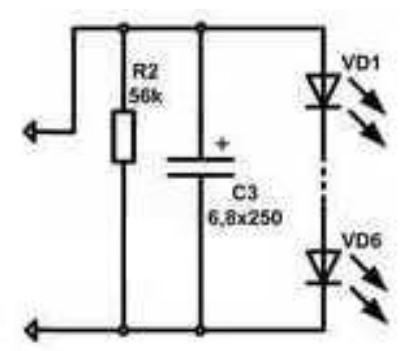

Figure 3: Diagram of LEDs showing the filling and depletion of water base fertilizer is used to prepare a fertilizer solution and add it to water in specified quantities.

Injectors take a small portion of concentrated fertilizer solution from a stock tank and inject it into the water line. In the recent studies, the device for preparing fertilizer solution (Ventura injector) (a), water pump $12 \mathrm{~V}$ was used [6]. A filter that purifies water in a pipe and a device that determines the pressure of water in a pipe, in one part. The spinner is designed to control the full water supply to the entire pipe section. Optoelectronic switch that transfers the dehydration of the plant to the water base was useful to further study. 


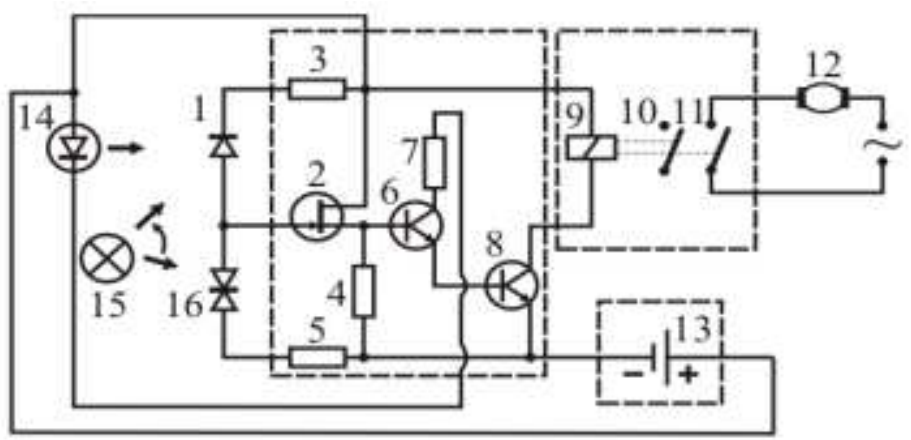

Figure 4: Diagram of the optoelectronic switch

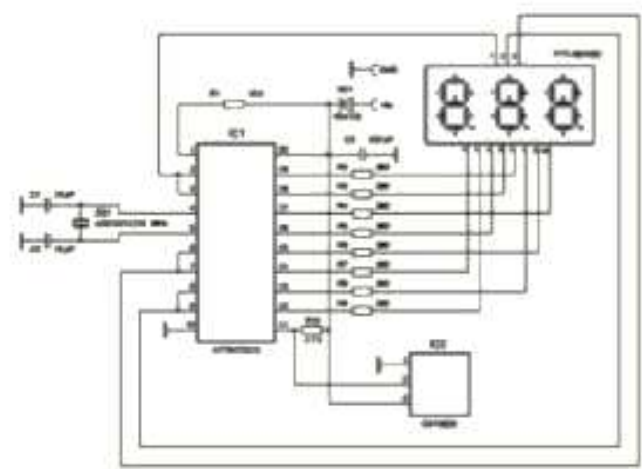

Figure 5: Thermo hygrometer for determining soil moisture and temperature

One of the most important soil indicators is $\mathrm{ph}$. The $\mathrm{Ph}$ is the indicator of hydrogen, which indicates the concentration of free hydrogen ions in water. To simplify this concept, ph is determined from the quantitative ratio of $\mathrm{N}+$ and $\mathrm{ON}$ - in water. For example: if there are many $\mathrm{N}+$ ions in the water, the acidity of water will be higher. The higher the content of $\mathrm{ON}$ - ions, the higher the alkalinity of the water.

Note. The pH level tends to rise spontaneously. In distilled water, these ions balance each other. In such cases, water $\mathrm{ph}=7$, i.e. neutral.

The acidity or alkalinity of the soil is directly related to its agrochemical properties and plant development.

Acid plays a key role in providing plants with nutrients. Vegetable crops grow very hard on soils with high acidity or alkalinity. Hence, it is unreasonable to expect high yields on such soils. High ( $\mathrm{pH}>9)$ or low $(\mathrm{pH}<4)$ soil $\mathrm{pH}$ is toxic to the roots of your plant.

In soils with optimal acidity, plants can easily absorb nutrients or mineral fertilizers, and the physical properties of soil are improved.

In soils with high acidity $\mathrm{pH}=4.0-5.5$, the following cases are observed:

- Iron, manganese are easily absorbed, but their concentration reaches toxic levels.

- $\quad$ Phosphorus, potassium, sulfur, calcium, magnesium and molybdenum are poorly absorbed.

- $\quad$ Plants are susceptible to disease and insect attacks.

- The activity of microorganisms stops.

- In soils with increased alkalinity, $\mathrm{pH}>7.5$, the following cases are observed: 
- Iron, manganese, phosphorus, copper, zinc, chalk and most microelements are difficult to assimilate.

- Reduced capillarity, water permeability and filtration properties of the soil.

- $\mathrm{pH}$ control.

Phosphoric acid is used to lower $\mathrm{pH}$ of nutrient solution, and potassium hydroxide to raise it. Or you can use the table from Table 1 below [17]:

\section{Table 1: pH control}

\begin{tabular}{|c|l|l|}
\hline № & \multicolumn{1}{|c|}{ Lowers $\mathbf{~ p H}$} & \multicolumn{1}{|c|}{$\mathbf{p H}$ raises } \\
\hline 1 & Phosphoric acid & Potassium hydroxide \\
\hline 2 & Sulfuric acid & Potassium carbonate \\
\hline 3 & Nitric acid & baking soda \\
\hline 4 & Lemon acid & \\
\hline
\end{tabular}

A device for determining soil $\mathrm{pH}$ is shown in Figure 6.

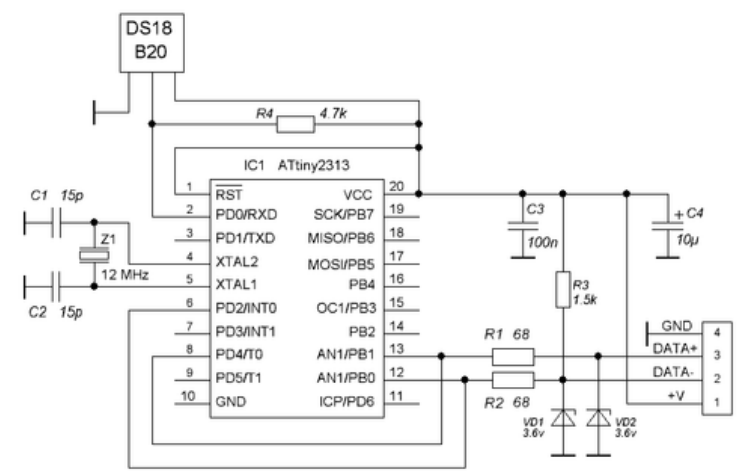

Figure 6: Device for determining soil pH.

Irrigation Hoses and Droppers Drip hoses are used to supply water from the distribution pipe to the plant root according to the needs of plants. Drip hoses are made of polyethylene and depending on the water consumption, in most cases there is a diameter of $\emptyset 16 \mathrm{~mm}$ and $\emptyset 20 \mathrm{~mm}$ or $\emptyset 12 \mathrm{~mm}$ in some cases. In practice, drip hoses are used as types of drip hoses that can be installed by cutting the hose.

For connecting the elements of drip irrigation system to each other, different types of connecting parts are used (angular, triple, connector, valve, etc.). Pressure regulator (dropper) valves are shown in recent studies [19].

The cost of building of the drip irrigation system. The cost of introducing a drip irrigation system depends on the specifics of the construction site and the type of crops. The cost of implementing a drip irrigation system in a garden planted according to the $4 \times 2.5 \mathrm{~m}$ scheme is shown in Table 2 .

Table 2: The cost of implementation of the drip irrigation system

\begin{tabular}{|l|c|c|}
\hline \multicolumn{1}{|c|}{ Device and cost type } & Amount & Price \\
\hline Territory of a modern garden & 5 ha & \\
\hline $\begin{array}{l}\text { The scheme of planting saplings } \\
4 \times 2,5 \mathrm{~m}\end{array}$ & 1 ha 1000 type & \\
\hline 1.Pool cooler & 1 type & 1.0 \\
\hline 2.Water pump with K25/32 mark & 1 type & 4.5 \\
\hline 3. Disc filter (with net) & 1 type & 2.2 \\
\hline
\end{tabular}




\begin{tabular}{|l|c|c|}
\hline 4.Fertilizer device ("Venturi”) & 1 type & 1.0 \\
\hline 5.Trunk pipe d=63m & $300 \mathrm{~m}$ & 3.4 \\
\hline 6. Distributing pipe & $500 \mathrm{~m}$ & 2.6 \\
\hline 7.Irrigation hoses d=16m & $12500 \mathrm{~m}$ & 10.0 \\
\hline 8. Droppers (41/hour) & 10,000 & 2.8 \\
\hline 9.Assisting and connecting parts & & \\
\hline 10. Construction materials & $30 \%$ & 9.3 \\
\hline 11. The cost of preparing project & & \\
\hline Totally & 5,0 ha & 40.3 \\
\hline
\end{tabular}

Note: The cost of the drip irrigation system depends on the tree planting scheme and based on its optimal design, construction costs can be reduced by almost half.

Benefits of drip Irrigation "Drip irrigation saves $20 \%$ to $80 \%$ of water compared to other irrigation methods, depending on the type of crops. Drip irrigation irrigates crops, but not fields. "The ISMITI survey results are presented in Table 3.

Table 3: The results showing the benefits of drip irrigation are from the ISMITI study

\begin{tabular}{|c|c|c|c|c|}
\hline $\begin{array}{c}\text { The place where } \\
\text { the research was } \\
\text { carried out }\end{array}$ & Type of crops & Water saving, $\%$ & $\begin{array}{l}\text { Resource (reducing } \\
\text { fuel, labour), \% }\end{array}$ & Increasing yield,\% \\
\hline \multirow{2}{*}{$\begin{array}{l}\text { Namangan district } \\
\text { Uychi district }\end{array}$} & Garden & 60 & 25 & - \\
\hline & Cotton & 65 & 60 & $90-156$ \\
\hline $\begin{array}{l}\text { Fergana region } \\
\text { Fergana district } \\
\end{array}$ & garden (peaches) & 32 & 25 & 108 \\
\hline \multirow{2}{*}{$\begin{array}{l}\text { Kashkadarya region } \\
\text { Kitob and Nishon } \\
\text { districts }\end{array}$} & vineyard & 30 & 30 & 25 \\
\hline & Cotton & 35 & 50 & 59 \\
\hline $\begin{array}{l}\text { Karakalpaxtan } \\
\text { Republic }\end{array}$ & Tomato & 54 & 60 & 65 \\
\hline
\end{tabular}

The yield increases and the quality of the crop improves. The yield increases up to $40 \%$ in orchards and vineyards, up to $80 \%$ in vegetables. Table 4 . The harvest leads to early ripening for 10-15 days.

Table 4: Productivity results

\begin{tabular}{|l|l|c|c|}
\hline \multirow{2}{*}{ Type of crops } & Measuring unit & \multicolumn{2}{c|}{ Medium yield } \\
\cline { 3 - 4 } & & Simple irrigation & Drip irrigation \\
\cline { 3 - 4 } & & & $50-55$ \\
\hline Cotton & c/ha & $25-30$ & $100-120$ \\
\hline Onion & c/ha & $50-60$ & $25-32$ \\
\hline Corn (grain) & c/ha & $6-7$ & $130-140$ \\
\hline Tomato (in open place) & c/ha & $25-30$ & $45-50$ \\
\hline Grape & c/ha & $20-25$ & $55-60$ \\
\hline Apple & c/ha & $10-15$ & $15-16$ \\
\hline Apricot & c/ha & $4-5$ & $18-20$ \\
\hline Peach & c/ha & $5-6$ & $45-50$ \\
\hline Potato & c/ha & $20-25$ & \\
\hline
\end{tabular}

The use of drip irrigation technique is significantly reduced. This technique is not used because the soil is not loosened and fertilizers are applied with water. The field is not cultivated, ditches are not used. Typically, the tractor enters 
the field 25-30 times, and with drip irrigation only 6-7 times. About 50-60 liters of diesel fuel per hectare are saved during the season. With drip irrigation, fertilizers are consumed much less frequently: With drip irrigation, the cost of year-round fertilizers is reduced by $30 \%$ ! The cost of fertilizers applied during the growing season has been reduced by $50 \%$. The absorption of fertilizers by plants exceeds $90 \%$ and usually does not exceed $30-40 \%$.

\section{CONCLUSIONS}

Drip irrigation significantly reduces labor work, since there are no ditches on the field, so the irrigator does not need to monitor the water, prepare the field for irrigation, that is, grass, cellophane and other equipment, only one irrigator can easily irrigate 10-20 hectares per day. Its labor productivity increases significantly. The number of swimmers is significantly reduced. In swimmers, the frequency of occupational diseases (boils, radiculitis, etc.) is significantly reduced. Land use efficiency is increasing. Crops are also grown in land that remains at the edge of the field due to the lack of tractors in the field. Water is not discharged from the field, as a result, the need for ditches is sharply reduced, the soil of the field is not eroded, the fertile soil layer is preserved, weed seeds do not fall into the field, since the water is filtered, the field does not overgrow. Soil re-salinization is reduced, excess water is not used to irrigate crops, and groundwater level does not rise. Seasonal soil salinization does not occur in fields with low groundwater levels. In winter, it is not necessary to wash the soil that has not been salted during the season. By reducing the salinity of soil leaching, costs for water, equipment (floor removal), labor work (saline washing) are reduced. In areas with low salinity, excavation of foundation pits is reduced. In vertical well areas, pump performance is reduced, resulting in significant energy savings. Local manufacturers of elements of drip irrigation systems SUE "Shurtangazkimyo" (Kashkadarya region) produces polyethylene granules, pipes, hoses, drip tapes, components. Pipe Technologies (Tashkent) manufactures pipes, irrigation hoses, drip tapes, accessories and drippers. Exim plast (Tashkent) manufactures pipes, drip hoses and accessories. LLC "Santexsplast" (Tashkent) produces components, filters and fertilizers. Private enterprise "Agroplast installation service" (Uychinsky district of Namangan region) produces pipes, hoses, accessories and bends. OOO "Spetspolymer" (Tashkent) produces pipes, irrigation hoses, accessories and droppers. Scientific and Consulting Center "Water-saving irrigation technologies" (Tashkent). The center conducts research to improve the use of water-saving technologies, develops proposals and recommendations, provides specific advice and projects. The center is the main organization that provides consulting services for the implementation and development of drip irrigation systems.

\section{REFERENCES}

1. Mirziyoyev Sh.M. Action strategy for five priority directions of development of Uzbekistan. Uzbekistan, 2017 my.gov.uz.

2. Yasonidi O.E. Drip irrigation. Novocherkassk: L., 2011. P 322.

3. Markov Yu.A. Research programs and methods for growing fruit and berry crops.USSR Ministry of Fruit and Vegetable Economy VNIIS im. I.V. Michurin. Michurinsk, 1985. p 116.

4. Storchous V.N. Research results on growing vegetables and fruits in winter in Crimea // Agricultural sciences: Scientific works of KATU. 2005. Issue. 90. Simferopol. p. 187-193.

5. Storchous V.N. Drip irrigation - a reserve of water economy in the cultivation of grapes, fruits and vegetables in the Crimea // Science Practices of the PF NUBIPU (KATU). Series "Rural Sciences". 2014. VIP. 161. Simferopol. p. 148-153

6. Khamidov M.Kh., Shukurlaev N.I., Mamataliev A.B., textbook "Agricultural hydro-reclamation", editorial board of the publishing house "Shark".Tashkent-2009. p 380 
7. Bezborodov A.G. Application of straw as organic fertilizer and moisture evaporation depressant in irrigated agriculture. Materials of the international scientific and practical conference.T .: UzSIIH, IWMI, 2007. - pp 9-13.

8. Bakiev R. Drip irrigation of the cotton plant during its cultivation on meadow-gray soil. J. "Agriculture of Uzbekistan". 2001, №.1.51 pp 36-37.

9. Artukmetov Z.A, Shodmanov M. Rational use of water in farms, advanced methods of irrigation and land reclamation. $T$.: Edition of ToshDAU. Department, 2004.p 50.

10. Artukmetov Z.A.., Sheraliev Kh. Sh. Fundamentals of irrigation of agricultural crops. T.: National Society of Philosophers of Uzbekistan, 2007. - p 320 .

11. Artukmetov Z.A., Allanov Kh. K. New technologies of irrigation and their use. T.: Editorial and publishing department of the Tashkent State Agrarian University, 2010. - p 116.

12. Azizov Sh. Influence of drip irrigation on water-physical properties and soil microclimate // Journal "Agro Ilm". Special issue - Tashkent, 2018, p 100.

13. KhamidovM.Kh., ShukrulaevKh.I., Begmatov I.A., Mamataliev A.B. Water use in agriculture. -Tashkent, 2014.p 120.

14. 14.R.T. Gazieva, A.M. Usmanov, E.O. Ozodov Automation of irrigation systems and its economic efficiency, Tashkent. 2017, $107 \mathrm{p}$.

15. Mamatov S.A. Drip irrigation system. Toshkent. 2016, $p 12$.

16. Raksimov K.T. Determination of device throughput // “Architecture. Construction Design Magazine, Tashkent, 2012. №2, pp 52-54 (05.00.00.№4)

17. Arifdzhanov A.M., Fatkhullaev A.M., Raksimov K.T. Distribution of velocities with uniform motion of suspended flow // Uzbek journal "Problems of Mechanics". - Tashkent, 2005. - No. 2. - pp 25-29. (05.00.00.№6)

18. Raksimov K.T., Abduraimova D.A., Dushulova N.A. Critical speed of movement of slurry in a cylindrical pipeline // Journal Vestnik TSTU, -Toshkent, 2012.-№1- 2.- p 60. (05.00.00.№16)

19. Rakhimov K., Khamraev S., Rasulov R. Turbulent flow // Scientific supplement of the Uzbek agricultural journal "Agroilm". Tashkent, 2010.-№3 (15). - S. 41-45. (05.00.00.№3) 